\title{
Effect of Plant Spacing and Fertilizer Management on the Yield Performance of BRRI dhan39 under Old Brahmaputra Floodplain Soil
}

\author{
S. Jahan, M.A.R. Sarkar and S.K. Paul* \\ Department of Agronomy, Bangladesh Agricultural University, Mymensingh 2202, Bangladesh
}

\begin{abstract}
An experiment was conducted at the Agronomy Field Laboratory, Bangladesh Agricultural University, Mymensingh, Bangladesh from June to December 2015 to investigate the effect of spacing and fertilizer management on the yield of transplanted Aman rice cv. BRRI dhan39. The experiment comprised of five spacings viz. $25 \times 5 \mathrm{~cm}, 25 \times 10 \mathrm{~cm}, 25 \times 15 \mathrm{~cm}, 25 \times 20 \mathrm{~cm}, 25$ $\times 25 \mathrm{~cm}$ and four fertilizer schedules viz. no manure and no fertilizer (control), recommended dose of inorganic fertilizer (80-60-40 kg N, $\mathrm{P}_{2} \mathrm{O}_{5}, \mathrm{~K}_{2} \mathrm{O} \mathrm{ha-1}$, respectively $+60 \mathrm{~kg} \mathrm{ha}^{-1}$ gypsum + $10 \mathrm{~kg} \mathrm{ha}^{-1} \mathrm{ZnSO}_{4}$ ), 75\% recommended dose of inorganic fertilizer + cow dung at $5 \mathrm{t} \mathrm{ha}^{-1}, 75 \%$ recommended dose of inorganic fertilizer + poultry manure @ $2.5 \mathrm{t} \mathrm{ha}^{-1}$. The experiment was laid out in a Randomized Complete Block Design with three replications. Plant height (104.60 $\mathrm{cm})$, number of total tillers hill-1 $(11.03)$, panicle length $(22.25 \mathrm{~cm})$, grains panicle ${ }^{-1}(109.00)$ and grain yield $\left(4.42 \mathrm{t} \mathrm{ha}^{-1}\right)$ were found to be the highest in $25 \times 15 \mathrm{~cm}$ spacing. Regarding nutrient management, $75 \%$ recommended dose of inorganic fertilizers + cow dung at $5 \mathrm{t} \mathrm{ha}^{-1}$ superseded other treatments in terms of plant height $(107.50 \mathrm{~cm})$, number of total tillers hill ${ }^{-1}(10.40)$, number of effective tillers hill $^{-1}(7.68)$, panicle length $(22.26 \mathrm{~cm})$, grains panicle ${ }^{-1}(111.70)$ and grain yield $\left(4.14 \mathrm{t} \mathrm{ha}^{-1}\right)$. The control treatment (no manures and no fertilizers) gave the lowest values for all these parameters. The highest grain yield $\left(4.57 \mathrm{t} \mathrm{ha}^{-1}\right)$ was found in $25 \times 15 \mathrm{~cm}$ spacing combined with $75 \%$ recommended dose of inorganic fertilizers + cow dung at $5 \mathrm{t} \mathrm{ha}^{-1}$ and the lowest grain yield $\left(2.50 \mathrm{t} \mathrm{ha}^{-1}\right)$ was found in $25 \times 5 \mathrm{~cm}$ spacing combined with control (no manures and fertilizers). Therefore, $25 \times 15 \mathrm{~cm}$ spacing combined with $75 \%$ recommended dose of inorganic fertilizers + cow dung at $5 \mathrm{t} \mathrm{ha}^{-1}$ appeared as the promising practice in transplant Aman rice cv. BRRI dhan 39 cultivation.
\end{abstract}

Key words: Spacing, Transplant Aman rice, Fertilizer management, Yield

Rice is the staple food for the people of Bangladesh. Besides, about half of the world's population depends on rice as staple food. Bangladesh has three types of rice according to growing seasons within a year viz. Aus, Aman and Boro. Aman rice of the country covers an area of $55,32,477$ ha with a production of $1,31,90,163$ metric tons (BBS, 2015). The yield of transplant Aman rice can be increased with improved cultivation practices like proper spacing of planting and proper fertilizer management. Plant spacing is an important factor which plays a significant role on growth, development and yield of rice. Spacing provides scope to the plants for efficient utilization of solar radiation and nutrients (Paul et al., 2017). Proper spacing supports the plants to uptake more nutrients from the soil. It may help to receive maximum LAI and light interceptions which facilitate efficient photosynthesis and ultimately yield of rice. Proper fertilizer management also plays an important role on yield and quality of rice crop. Pal et al. (2016) reported that grain yield and grain protein content of aromatic rice increased due to application $75 \%$ of recommended dose of inorganic fertilizers supplemented with cowdung $10 \mathrm{t} \mathrm{ha}^{-1}$.

*Corresponding author email: skpaull@gmail.com
Similar results were also reported elsewhere (Sarkar et al., 2014; Ray et al., 2015 and Biswas et al., 2016).

Soil fertility status of Bangladesh is gradually declining. Most of the soil of Bangladesh has organic matter less than $1.5 \%$ and in many cases it is less than 1\% (BARC 2005). Nutrient mining and depletion of soil organic matter have been identified as reasons of yield stagnation or decline in the productivity of crops. Improper soil management practices and the use of chemical fertilizer with no or very little use of manure throughout the year may be responsible for this. It has already been indicated that the imbalanced use of fertilizer has tremendous pressure on the soil organic matter and nutrients resulting in the decrease of crop production. Among the cultural practices, integrated nutrient management like application of cow dung, poultry manure along with other inorganic fertilizers is very much important (Marzia et al., 2016) which can improve the grain yield of rice. In order to improve crop productivity more emphasis should be given on spacing and suitable fertilizer management.

\section{Material and Methods}

The experiment was conducted at the Agronomy 
Field Laboratory, Bangladesh Agricultural University, Mymensingh, during July to December 2015 to study the effect of spacing of transplanted rice and fertilizer management on Aman rice cv. BRRI dhan39. The experimental site belongs to the Sonatola Soil Series of Old Brahmaputra Floodplain (AEZ 9) having noncalcareous dark grey floodplain soil. The land was medium high with sandy loam texture having $\mathrm{pH}$ 5.9. The experiment comprised of five spacings viz. $25 \times 5 \mathrm{~cm}\left(\mathrm{~S}_{1}\right), 25 \times 10 \mathrm{~cm}\left(\mathrm{~S}_{2}\right), 25 \times 15 \mathrm{~cm}\left(\mathrm{~S}_{3}\right)$, $25 \times 20 \mathrm{~cm}\left(\mathrm{~S}_{4}\right), 25 \times 25 \mathrm{~cm}\left(\mathrm{~S}_{5}\right)$ and four fertilizer treatments viz. no manure and no fertilizer (control) (N0), recommended dose of chemical fertilizer (80-60-40 kg N, $\mathrm{P}_{2} \mathrm{O}_{5}, \mathrm{~K}_{2} \mathrm{O}$ ha $^{-1}+60 \mathrm{~kg} \mathrm{ha}^{-1}$ gypsum $\left.+10 \mathrm{~kg} \mathrm{ha}^{-1} \mathrm{ZnSO}_{4}\right)\left(\mathrm{N}_{1}\right), 75 \%$ recommended dose of inorganic fertilizer + cow dung at $5 \mathrm{t} \mathrm{ha}^{-1}\left(\mathrm{~N}_{2}\right), 75 \%$ recommended dose of inorganic fertilizer + poultry manure @ $2.5 \mathrm{t} \mathrm{ha}^{-1}\left(\mathrm{~N}_{3}\right)$. The experiment was laid out in a Randomized Complete Block Design with three replications. The size of unit plot was $4.0 \times 2.5$ $\mathrm{m}$. The experimental plots were fertilized according to the treatments at final land preparation. Nitrogen was applied as per experimental specification in the form of urea in three equal splits at 15,30 and 45 days after sowing. Prior to harvest, five hills plot $^{-1}$ were randomly selected excluding border hills and at centre of the plot one square metre harvest area from each unit plot was selected for recording data on yield components. The crop was harvested at full maturity and threshed by pedal thresher to record the fresh weight of grain and straw $1 \mathrm{~m}^{-2}$ plot-wise. Grains were cleaned and sun dried to a moisture content of $14 \%$. Straws were also sundried properly. Grain and straw yields were then converted to $\mathrm{t} \mathrm{ha}^{-1}$. The recorded data were analyzed statistically using "Analysis of Variance Technique and the differences among treatment means were adjudged by Duncan's Multiple Range Test (DMRT) (Gomez and Gomez, 1984).

\section{Results and Discussion \\ Effect of plant spacing}

Spacing in transplanted rice significantly influenced on crop characters, yield and yield components except 1000-grain weight (Table 1).

Table 1. Effect of spacing of transplanting on crop characters, yield components and yield of transplant Aman rice cv. BRRI dhan39

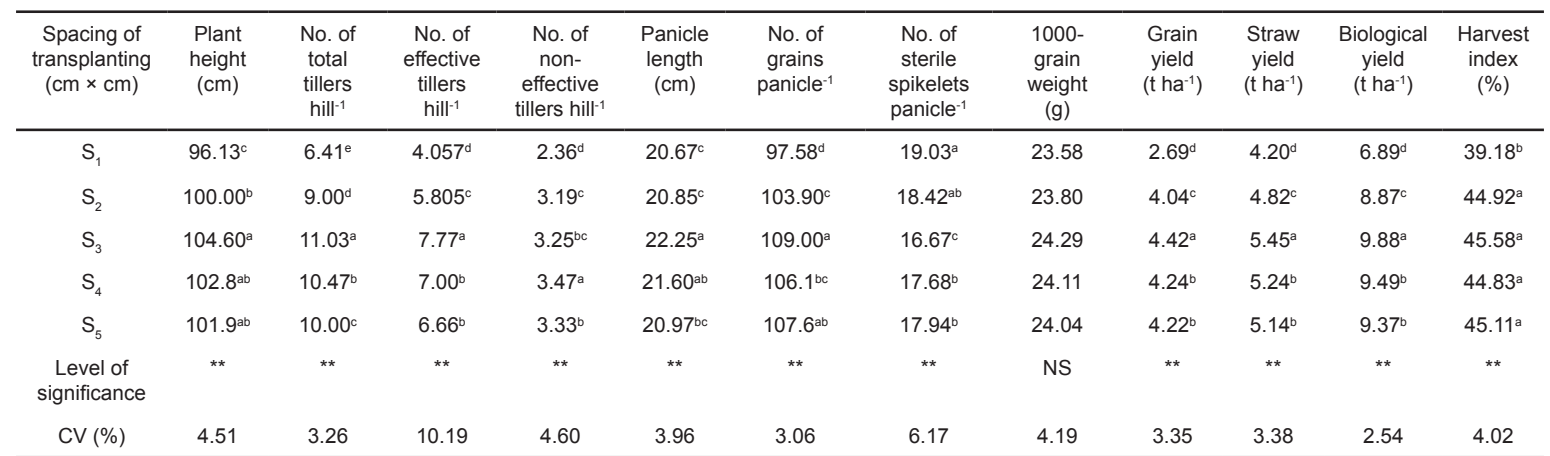

In a column, figures with same letter (s) or without letter do not differ significantly whereas figures with dissimilar letter differ significantly (as per DMRT). $\mathrm{S}_{1}=25$ $\times 5 \mathrm{~m}, \mathrm{~S}_{2}=25 \times 10 \mathrm{~cm}, \mathrm{~S}_{3}=25 \times 15 \mathrm{~cm}, \mathrm{~S}_{4}=25 \times 20 \mathrm{~cm}, \mathrm{~S}_{5}=25 \times 25 \mathrm{~cm}$, ${ }^{* *}=$ Significant at $1 \%$ level of probability, NS = Not significant.

The tallest plant $(104.60 \mathrm{~cm})$ was obtained in $25 \times 15 \mathrm{~cm}$ spacing followed by $25 \times 20 \mathrm{~cm}$ spacing $(102.40 \mathrm{~cm})$ and the shortest plant $(96.13 \mathrm{~cm})$ was obtained in $25 \times 5 \mathrm{~cm}$ spacing. The highest plant height might have resulted due to inception of optimum solar radiation in $25 \times 15 \mathrm{~cm}$ spacing facilitating better photosynthesis.

More number of total tillers hill-1 ${ }^{-1}(11.03)$ as well as effective tillers hill ${ }^{-1}$ (7.77) were found in $25 \times 15$ $\mathrm{cm}$ spacing, might be due to the capturing more solar radiation. The lowest number of total tillers hill $^{-1}$ (6.41) and effective tillers hill-1 (4.05) were found in $25 \times 5 \mathrm{~cm}$ spacing. Wider spacing produced higher number of effective tillers hill ${ }^{-1}$, where the plant could exploit more sunlight for photosynthesis resulting in the accumulation of more carbohydrate, thereby increasing the number of effective tillers hill-1. This result is in agreement with the findings of Salahuddin et al. (2009). The highest panicle length $(22.25 \mathrm{~cm})$ was observed in $25 \times 15 \mathrm{~cm}$ spacing followed by $25 \times 20 \mathrm{~cm}(21.60 \mathrm{~cm})$ and the shortest one $(20.67$ $\mathrm{cm}$ ) was found in $25 \times 5 \mathrm{~cm}$ spacing. Panicle length varied due to spacing was observed by Ray et al.
(2015) and Tari et al. (2009). The highest number of grains panicle ${ }^{-1}(109.00)$ was recorded in $25 \times 15$ $\mathrm{cm}$ spacing followed by $25 \times 25 \mathrm{~cm}(107.60)$ and the lowest number of grains panicle ${ }^{-1}(97.58)$ was recorded in $25 \times 5 \mathrm{~cm}$ spacing. The highest number of sterile spikelets panicle ${ }^{-1}$ (19.03) was observed in $25 \times 5 \mathrm{~cm}$ spacing and the lowest number (16.67) was observed in $25 \times 15 \mathrm{~cm}$ spacing. Similar results were reported by Verma et al. (2002). The highest grain yield $\left(4.42 \mathrm{t} \mathrm{ha}^{-1}\right)$ was recorded in $25 \times 15 \mathrm{~cm}$ spacing followed by $25 \times 20 \mathrm{~cm}$ spacing $\left(4.24 \mathrm{t} \mathrm{ha}^{-1}\right)$ and the lowest grain yield $\left(2.69 \mathrm{t} \mathrm{ha}^{-1}\right)$ was obtained from $25 \times 5 \mathrm{~cm}$ spacing. The highest number of effective tillers hill ${ }^{-1}$ and the highest number of grains panicle $^{-1}$ were recorded in $25 \times 15 \mathrm{~cm}$ spacing were mainly responsible for the highest grain yield. Lower grain yield obtained in closer spacing might be due to improper utilization of nutrient and space. Similar results were recorded by Salahuddin et al. (2009). Results revealed that straw yield $\left(5.45 \mathrm{t} \mathrm{ha}^{-1}\right)$ and biological yield $\left(9.88 \mathrm{t} \mathrm{ha}^{-1}\right)$ were the highest in $25 \times$ $15 \mathrm{~cm}$ spacing, while $25 \times 5 \mathrm{~cm}$ spacing produced 
the lowest straw yield $\left(4.20 \mathrm{t} \mathrm{ha}^{-1}\right)$. The highest harvest index (45.58\%) was obtained from $25 \times 15$ cm spacing, which was statistically identical to $25 \times$ $10 \mathrm{~cm}, 25 \times 20 \mathrm{~cm}$ and $25 \times 25 \mathrm{~cm}$.

Table 2. Effect of fertilizer management on crop characters, yield components and yield of transplant Aman rice Cv. BRRI dhan 39

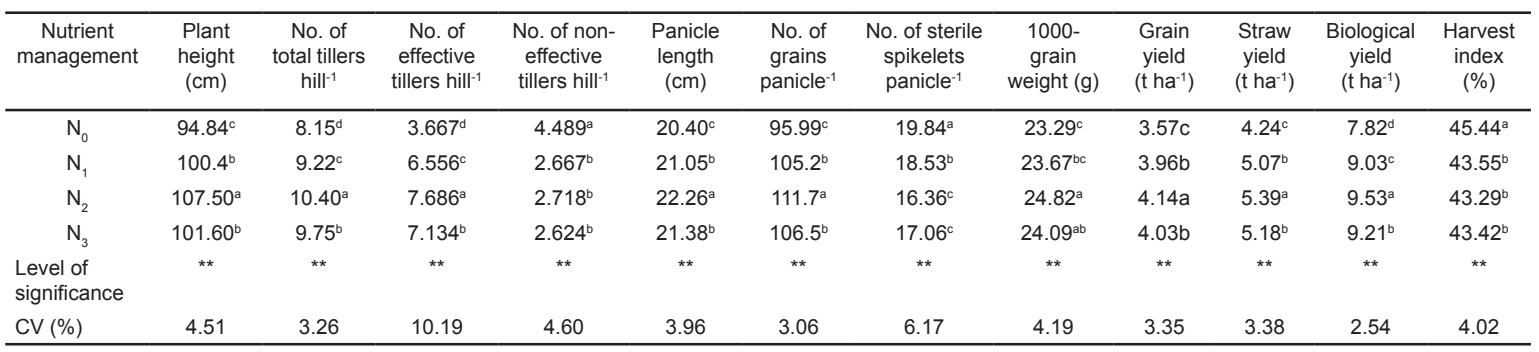

In a column, figures with same letter (s) or without letter do not differ significantly whereas figures with dissimilar letter differ significantly (as per DMRT). $\mathrm{N}_{0}=$ No manure and no fertilizer (control), $\mathrm{N}_{1}=$ Recommended dose of chemical fertilizer (80-60-40 kg N, $\mathrm{P}_{2} \mathrm{O}_{5}, \mathrm{~K}_{2} \mathrm{O} \mathrm{ha}{ }^{-1}$, respectively $+60 \mathrm{~kg} \mathrm{ha}^{-1}$ gypsum $+10 \mathrm{~kg}^{-1}$ $\mathrm{ZnSO}_{4}$ ), $\mathrm{N}_{2}=75 \%$ recommended dose of inorganic fertilizer + cow dung at $5 \mathrm{t} \mathrm{ha}^{-1}, \mathrm{~N}_{3}=75 \%$ recommended dose of inorganic fertilizer + poultry manure @ $2.5 \mathrm{t} \mathrm{ha-1}$. * $=$ Significant at $1 \%$ level of probability.

Either decreasing or increasing plant spacing other than $25 \times 15 \mathrm{~cm}$ showed decreased trend in harvest index. The lowest harvest index (39.18\%) was recorded in $25 \times 5 \mathrm{~cm}$ spacing (Table 1 ).

Table 3. Effect of interaction between spacing of transplanting and fertilizer management on crop characters, yield components and yield of transplant Aman rice cv. BRRI dhan 39

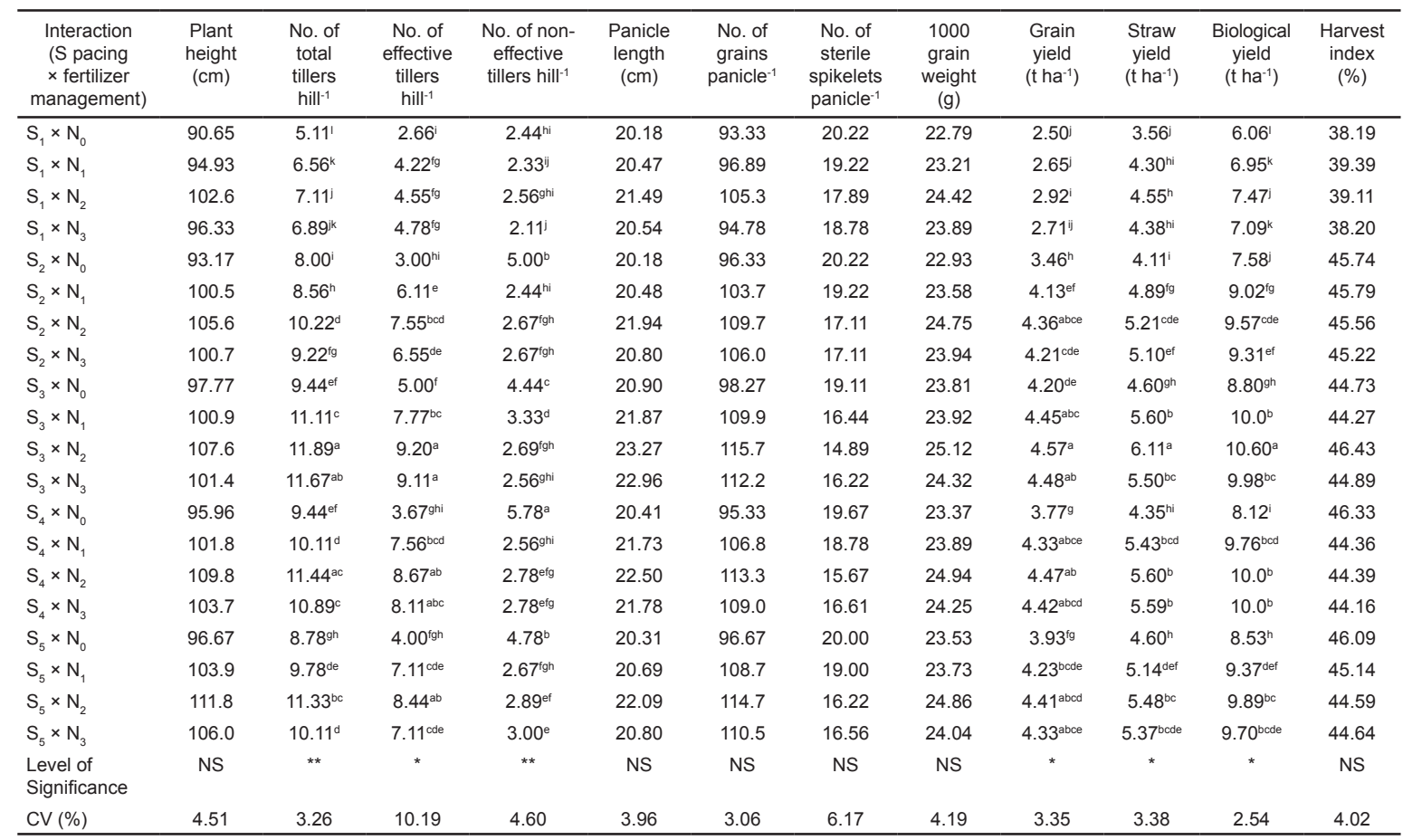

Figures in column under each factor of treatment having the same letter or without letter do not differ significantly whereas figures with dissimilar letter(s) differ significantly as per DMRT. $S=25 \times 5 \mathrm{~cm}, \mathrm{~S}_{=}=25 \times 10 \mathrm{~cm}, \mathrm{~S}_{3}=25 \times 15 \mathrm{~cm}, \mathrm{~S}=25 \times 20 \mathrm{~cm}, \mathrm{~S}_{\mathrm{s}}=25 \times 25 \mathrm{~cm}$. N = No manure and no fertilizer (control), N= Recommended dose of chemical fertilizer (80-60-40 kg N, $\mathrm{P}_{2} \mathrm{O}_{5}, \mathrm{~K}_{2} \mathrm{O}$ ha $^{-1}$, respectively $+60 \mathrm{~kg} \mathrm{ha}^{-1}$ gypsum $\left.+10 \mathrm{~kg} \mathrm{ha}^{-1} \mathrm{ZnSO}_{4}\right), \mathrm{N}_{2}=75 \%$ recommended dose of inorganic fertilizer + cow dung at $5 \mathrm{t} \mathrm{ha}^{-1}, \mathrm{~N}_{3}=75 \%$ recommended dose of inorganic fertilizer + poultry manure @ $2.5 \mathrm{t} \mathrm{ha}^{-1} .{ }^{* *}=$ Significant at $1 \%$ level of probability, ${ }^{*}=$ Significant at $5 \%$ level of probability, NS = Not significant.

\section{Effect of fertilizer management}

Fertilizer management significantly influenced crop characters, yield components and yield except 1000 -grain weight (Table 2). The application of $75 \%$ of recommended dose of inorganic fertilizer + cow dung at $5 \mathrm{t} \mathrm{ha}^{-1}$ showed superiority in terms of plant height $(107.50 \mathrm{~cm})$, number of total tillers hill- $^{-1}(10.40)$, number of effective tillers hill ${ }^{-1}$ (7.68), panicle length $(22.26 \mathrm{~cm})$ and grains panicle ${ }^{-1}(111.70)$, while the lowest values for those parameters were found in control plots. The highest grain yield $\left(4.14 \mathrm{t} \mathrm{ha}^{-1}\right)$, straw yield $\left(5.39 \mathrm{t} \mathrm{ha}^{-1}\right)$ and biological yield $\left(9.53 \mathrm{t} \mathrm{ha}^{-1}\right)$ were obtained when the crop was fertilized with $75 \%$ of recommended dose of inorganic fertilizer + cow dung at $5 \mathrm{t} \mathrm{ha}^{-1}$. Probably this treatment might have provided adequate nutrients to the plants and due to absorption of more nutrients, the crop produced the highest grain yield.

These results are in agreement with that of Shaha et al. (2014) and Sarkar et al. (2014) who found differences in yield and yield contributing characters due to different levels of nutrient management. The treatment control (no manures and fertilizers) gave the lowest values for the same parameters due to poor nutrient supply and it uptake by plant. The lowest number of non-effective tillers hill-1 (2.62) 
was found in treatment $75 \%$ of recommended dose of inorganic fertilizers + poultry manure at $2.5 \mathrm{t} \mathrm{ha}^{-1}$. Application of $75 \%$ of recommended dose of inorganic fertilizers + cow dung at $5 \mathrm{t} \mathrm{ha}^{-1}$ improved the yield contributing characters viz. number of effective tillers hill $^{-1}$ and number of grains panicle ${ }^{-1}$, which ultimately resulted in the highest grain yield. The straw yield showed similar trend as that of grain yield due to nutrient management. Application of different doses of manures and fertilizers influenced the vegetative growth in terms of plant height and number of total tillers hill ${ }^{-1}$, which resulted in differences of straw yield. The highest harvest index $(45.44 \%)$ was found in control treatment (no fertilizer and manure application). The lowest harvest index (39.44\%) was found in $75 \%$ recommended dose of inorganic fertilizer + cow dung at $5 \mathrm{t} \mathrm{ha}^{-1}$.

\section{Effect of interaction between spacing of transplanting and fertilizer management}

Number of total tillers hill $^{-1}$, grain yield and straw yield of transplant Aman rice were significantly affected by interaction between spacing and fertilizer management. The highest number of effective tillers hill $^{-1}(9.20)$ was found in the treatment combination of $25 \times 15 \mathrm{~cm}$ spacing and $75 \%$ recommended dose of inorganic fertilizer + cow dung at $5 \mathrm{t} \mathrm{ha}^{-1}$, which was statistically identical $(9.11)$ to $25 \times 15 \mathrm{~cm}$ spacing and $75 \%$ recommended dose of inorganic fertilizer + poultry manure at $2.5 \mathrm{t} \mathrm{ha}^{-1}$. The results showed superiority in terms of highest number of total tillers hill $^{-1}$ (11.89), grain yield $\left(4.57 \mathrm{t} \mathrm{ha}^{-1}\right)$, straw yield $\left(6.11 \mathrm{t} \mathrm{ha}^{-1}\right)$ and biological yield $\left(10.60 \mathrm{t} \mathrm{ha}^{-1}\right)$ in the combination of $25 \times 15 \mathrm{~cm}$ spacing fertilized with $75 \%$ recommended dose of inorganic fertilizer + cow dung at $5 \mathrm{t} \mathrm{ha}^{-1}$. Sarkar et al. (2014) reported that BRRI dhan 34 fertilized with $75 \%$ recommended dose of inorganic fertilizer + cow dung at $5 \mathrm{t} \mathrm{ha}^{-1}$ produced the highest grain yield. Integration of poultry manure @ 5 $\mathrm{t} \mathrm{ha}^{-1}$ with $1.8 \mathrm{~g}$ USG at $25 \times 20 \mathrm{~cm}$ spacing increased the yield components and grain yield of monsoon rice $\mathrm{cv}$. BRRI dhan39 (Sarkar et al., 2016). The interaction of 25 $\times 5 \mathrm{~cm}$ spacing and control treatment (no manures and fertilizer) gave the lowest values in case of total tillers hill $^{-1}$ (5.11), effective tillers hill-1 (2.66) and grain yield $\left(2.50 \mathrm{t} \mathrm{ha}^{-1}\right)$ due to lack of proper nutrient supply and its uptake. The highest number of non-effective tillers hill-1 was recorded from $25 \times 20 \mathrm{~cm}$ with control fertilizers (5.78) and the lowest number of non-effective tillers hill $^{-1}$ (2.11) was recorded from $25 \times 5 \mathrm{~cm}$ fertilized with $75 \%$ recommended dose of inorganic fertilizer + poultry manure@ $@ 2.5$ t ha $^{-1}$, which was statistically identical to 25 $\times 5 \mathrm{~cm}$ with recommended dose of chemical fertilizer (80-60-40 kg N, $\mathrm{P}_{2} \mathrm{O}_{5}, \mathrm{~K}_{2} \mathrm{O}$ ha $^{-1}$, respectively $+60 \mathrm{~kg}$ $\mathrm{ha}^{-1}$ gypsum $+10 \mathrm{~kg} \mathrm{ha}^{-1} \mathrm{ZnSO}_{4}$.

\section{Conclusion}

Transplant Aman rice (cv. BRRI dhan39) can be cultivated using a spacing of $25 \times 15 \mathrm{~cm}$ combined with $75 \%$ recommended dose of inorganic fertilizer + cow dung at $5 \mathrm{t} \mathrm{ha}^{-1}$ to obtain the highest grain and straw yields thereby curtailing $25 \%$ of the recommended dose of fertilizers.

\section{References}

BARC (Bangladesh Agricultural Research Council). 2005. Fertilizer Recommendation Guide, Bangladesh Agricultural Research Council, Farmgate, Dhaka.

BBS (Bangladesh Bureau of Statistics). 2015. Year book agricultural statistics, Ministry of planning, Govt. People's Republic of Bangladesh, Dhaka. pp : 37- 49.

Biswas, T., Paul, S. K., Sarkar, M. A. R. and Sarkar, S. K. 2016. Integrated use of poultry manure with prilled urea and urea super granules for improving yield and protein content of aromatic rice (cv. BRRI dhan50). Progressive Agriculture, 27 (2) : 86-93.

Gomez, K. A., and Gomez, A. A. 1984. Statistical Procedure for Agricultural Research. Intl. Rice Res. Inst., Philippines, John Wiley and Sons. New York, Chichester, Brisbane, Toronto, Singapore. p : 680.

Marzia, R., Sarkar, M. A. R., and Paul, S K. 2016. Effect of row arrangement and integrated nutrient management on the yield of aromatic fine rice (cv. BRRI dhan34). International Journal of Plant \& Soil Science, 13(5) : 1-8.

Pal, S., Paul, S.K., Sarkar, M.A.R. and Gupta, D.R. 2016. Response on yield and protein content of fine aromatic rice varieties to integrated use of cowdung and inorganic fertilizers. Journal Crop and Weed, 12 (1) : 1-6.

Paul, S. K., Roy, B., Hasan, A.K. and Sarkar, M.A.R. 2017. Yield and yield components of short duration transplant Aus rice (cv. Parija) as influenced by plant spacing and nitrogen level. Fundam Appl Agric., 2(2) : 233-236

Ray, S., Sarkar, M.A.R., Paul, S.K., Islam, A.K.M.M. and Yeasmin, S. 2015. Variation of growth, yield and protein content of transplant Aman rice by three agronomic practices. Agricultural and Biological Sciences Journal, 1 (4) : $167^{-1} 76$.

Sarkar, M.A.R., Zobaida, M.R., Yeasmin, S. and Islam, A.K.M.M. 2016. Integrated nitrogen management of monsoon rice under two different plant spacings. Fundam Appl Agric., 1(3) : $124^{-1} 29$.

Sarkar, S. K., Sarkar, M.A.R., Islam N. and Paul, S.K. 2014. Yield and quality of aromatic fine rice affected by varietyand nutrient management. Bangladesh J. Agril. Univ., 12(2) :279-284.

Salahuddin, K. M., Chowhdury, S. H., Munira, S., Islam, M. M. and Parvin, S. 2009. Response of nitrogen and plant spacing of transplanted Aman rice. Bangladesh J. Agril. Res., 34(2) : 279-285.

Shaha, U., Bhuiya, M. S. U. and Paul, S. K. 2014. Integrated use of cowdung and inorganic fertilizer on the performance of modern varieties of transplant Aman rice. J. Agrofor. Environ., 8(2) : 81-84.

Tari, D. V., Pirdashti, H. A. and Nasiri, M. 2009. Investigation Some Agronomical Traits of Rice Under Different Transplanting Dates, Planting Space and Nitrogen Fertilization Levels in North of Iran. World Appl. Sci. J., 6 (8) : 1021- 1027.

Verma, A. K., Pandey, N. and Tripathi, S. 2002. Effect of transplanting spacing and number of seedlings on productive tillers, spikelets sterility, grain yield and harvest index of hybrid rice. Intl. Rice Res. Notes, 57: 1-51. 